\title{
Cheap Labour and A New Market: Canada's Seasonal Agricultural Workers Program and its Effects on Mexico. \\ Miranda Minawi
}

Documented, undocumented, permanently, temporarily, internally, externally - each year Mexico sees thousands of its citizens migrate. Approximately 13000 of those will travel to Canada to work in fields and greenhouses for the planting, growing and harvesting seasons, only to return to their families in Mexico for a few months. ${ }^{1}$ These temporary workers are a part of the Seasonal Agricultural Workers Program (SAWP), which is an initiative on the part of Human Resources and Skills Development Canada (HRSDC) with the Mexican Secretaría del Trabajo y Previsión Social (STPS, Ministry of Work and Social Security). Despite responsibilities that the employers and both governments have to the workers, they often face dangerous conditions, low wages and discrimination. Through the use of the dependency paradigm, this paper will argue that exploitation is faced on all fronts by the workers of the Seasonal Agricultural Workers Program. The temporary agricultural workers play a key role in the competitiveness of Canada's agricultural exports, but it is clear to see that in developing Canada's agribusinesses and economy, Mexican workers are being exploited to the detriment of both the individual workers and the Mexican economy.

The SAWP came into effect in 1966 and was due to post World War Two socioeconomic changes that made a lasting impact on Canadian labour and agriculture. In 1941, agricultural workers made up $29 \%$ of Canada's work force, but that number dipped to only $8 \%$ by 1966 . $^{2}$ This was due in part to the decline of the family farm and increased urbanization as people went in search of better jobs. As a result, there was a huge labour gap in the agricultural industry that needed to be filled, or else food could not have been effectively produced in Canada. It was decided that temporary workers from other countries, or near-shore labour, would be the solution. The program began with 264 Jamaican workers ${ }^{3}$ but was soon extended to other Caribbean countries and Mexico. ${ }^{4}$ A special citizenship category was created expressly for these

\footnotetext{
${ }^{1}$ Clarkson, S. (2008). Does North America exist? Governing the continent after NAFTA and 9/11. Toronto: University of Toronto Press. Pp. 426.

${ }^{2}$ Ibid.

${ }^{3}$ Ibid, pp 427.

${ }^{4}$ Ibid.
} 
temporary workers - "foreign workers." 5 It was designed so that it would be legal to restrict the mobility of the workers both to other areas of the labour market and other areas of the country. This way, the labour was ensured to stay within the agricultural sector and generally with a single farm for the duration of the season. ${ }^{6}$ The classification of "foreign workers" is a contentious one today and is at the root of a large part of the exploitation faced by these workers, as will be later addressed. Currently, approximately $98 \%$ of all SAWP participants are male, and around one half of the workers were from Mexico in $2006 .^{7}$ Given the large proportion of Mexican participants in SAWP, it is especially important to review the Mexican-Canadian relationship on this matter.

Presently, there are a variety of contractual obligations that the employers have and responsibilities of the state that would theoretically protect the workers, but in reality these are not practiced. The employer is obligated to pay a portion of the worker's airfare to and from Canada, to provide free housing to the worker that meets provincial and/or municipal standards, to ensure that workers' compensation and health insurance are available to the worker, and to sign a contract with regards to wages, duties, transport, accommodation and health and safety. ${ }^{8}$ At the same time, it is the provincial or municipal government's duty to ensure the buildings and tasks are up to the appropriate standard, and it is the role of the Mexican Consulate to monitor conditions for the protection of the Mexican workers. ${ }^{9}$ However, the Consulate has a conflicting role, because it is also supposed to mediate disputes and repatriate any troublesome workers. ${ }^{10}$ As of 2002, there were only 5 consular officers in Ontario to address 7633 workers, ${ }^{11}$ and the tendency of these officers to act in favour of the employers so as to protect the contracts gives rise to a system that truly gives no protection to the workers. The workers often use pesticides and other chemicals without proper training or safety equipment and have little access to doctors when needed, despite paying taxes and other deductions, and despite healthcare being contractually guaranteed. $^{12}$ They frequently work 10 hour days, 7 days a week at minimum

\footnotetext{
${ }^{5}$ Ibid, pp 428.

${ }^{6}$ Ibid.

${ }^{7}$ Ibid, pp 427.

${ }^{8}$ Seasonal Agricultural Workers - Government of Canada - Foreign Worker Program. (n.d.). Human Resources and Skills Development Canada. Retrieved July 17, 2011, from http://www.hrsdc.gc.ca/eng/workplaceskills/foreign_workers/ei_tfw/saw_tfw.shtml

${ }^{9}$ Lee, M. S. (Director). (2003). El Contrato [Documentary]. Canada: National Film Board.

${ }^{10}$ Clarkson, pp 429.

${ }^{11}$ Ibid.

${ }^{12}$ Lee, M.S. (Director)
} 
wage, only to return to cramped and sometimes unsafe housing. ${ }^{13}$ The seasonal workers face conditions that no Canadian would accept, but because they are classified as "foreign workers" they are not protected under the Canadian Charter of Rights and Freedoms, and so are not permitted to bargain collectively. ${ }^{14}$ The inability of workers to protect themselves from abuses, and the unwillingness on the part of the governmental institutions designated for that purpose show that the development of Canadian agriculture is at the expense of 13000 Mexican workers annually.

The Seasonal Agricultural Worker Program is purported to be beneficial to all involved, and admittedly on some level it is. The remittances, or money sent from the workers to their families in Mexico, do benefit the individuals and the country. In 2002, the average Mexican SAWP worker earned $\$ 9100$ and sent $\$ 4800$ home in remittances. ${ }^{15}$ In contrast, had the worker remained in Mexico and done similar work, he or she would have earned on average $\$ 900$ in the same time period. ${ }^{16}$ Remittances from temporary workers and other migrants make up an enormous portion of Mexico's capital - in 1995, they made up 57\% of all foreign investment. ${ }^{17}$ It would seem that these figures are beneficial to Mexico, but it is found that when remittances are used for daily expenses and not reinvested into the community, there is only a very limited multiplying factor. ${ }^{18}$ An example of a multiplying effect would be remittances used to invest in local infrastructure and businesses, creating growth in the local economy. In the case of the temporary migrants through the SAWP, J. Hennebry found that 23 of 25 workers surveyed sent money home for the purpose of household expenses. ${ }^{19}$ Part of the reason for this is that the workers accepted into the program are specifically chosen because they have families at home to send remittances to, and strong motivation to return to Mexico at the end of the harvesting season. $^{20}$ These factors combined show that the remittances, though they are a large part of Mexico's economy, will tend to be used for basic living expenses and do not tend towards significant reinvestment or other multiplying factors. While the remittances may benefit the

\footnotetext{
${ }^{13}$ Ibid.

${ }^{14}$ Clarkson, pp 430.

${ }^{15}$ Ibid, pp 432.

${ }^{16}$ Ibid.

${ }^{17}$ Verduczo, G., \& Unger, K. (1998). The impact of migration on economic development in Mexico. Migration, free trade and regional integration in North America (pp. 108). Paris: Organisation for Economic Co-operation and Development.

${ }^{18}$ Ibid, pp 109

${ }^{19}$ Hennebry, J. (2008). Bienvenidos a Canadá? Globalization and the Migration Industry. Canadian Studies in Population, 35(2). Retrieved July 17, 2011, from http://www.canpopsoc.org/journal/CSPv35n2p339.pdf

${ }^{20}$ Lee, M.S. (Director).
} 
individuals (at the cost of working in dangerous conditions with no labour mobility) and have a limited positive impact on the Mexican economy, the benefit for the Canadian economy is much greater. Agriculture and food made up 8.3\% of Canada's GDP in 2003, with exports of $\$ 24.4$ billion. $^{21}$ These exports have included a huge increase since 1990 in exports of tomatoes and cucumbers to Mexico- the very crops that the Mexican participants of SAWP are planting, growing and harvesting. ${ }^{22}$ In drawing agricultural workers away from Mexico and sending food exports there simultaneously, the Canadian agricultural economy benefits greatly and has become more developed. But in exporting food that could be grown within Mexico and drawing away working age males, there is a side effect of under developing the Mexican economy. Canada is using Mexico for cheap labour and as a new market for the agriculture industry.

A neoliberal institutional scholar would argue that Canada and Mexico are co-operating because it is in the interests of both economies, and that international institutions will help to regulate the program and eventually end the exploitation of SAWP participants. This has already been proven to be incorrect - Canada has been impervious to pressures from the international community in creating better conditions for SAWP participants. NAFTA for example provides mobility and other protections for skilled workers and business people, but cannot provide any protection for unskilled labourers such as the farmhands that participate in SAWP. ${ }^{23}$ The North American Agreement on Labour Cooperation (NAALC) that was part of NAFTA created a commission with a mandate to create better treatment for non-professional workers in North America $^{24}$ but only applies to sectors which fall under federal jurisdiction. Agriculture is a provincial responsibility in Canada, and therefore is out of the NAALC created commission, therefore failing to provide any protections for agricultural workers in Canada, domestic or foreign. The final ineffective international institution that fails to better conditions for temporary workers in Canada is the United Nations. The UN Convention on the Protection of the Rights of Migrant Workers and Members of their Families has not been signed by Canada. ${ }^{25}$ This indicates unwillingness on the part of the Canadian government to alter the exploitative status

\footnotetext{
${ }^{21}$ Clarkson, pp 429.

${ }^{22}$ Ibid.

${ }^{23}$ Ibid, pp 430.

${ }^{24}$ Ibid.

${ }^{25}$ Drache, D. (2008). Big picture realities: Canada and Mexico at the crossroads. Waterloo, Ont.: Wilfrid Laurier University Press.
} 
quo. If global governance via international institutions was as effective as believed by the idealist neoliberal institutionalists then the combination of UN conventions and the details of NAFTA would protect the vulnerable workers of the SAWP. Evidently, this is not the case. Workers will continue to be exploited and the Mexican economy will continue to be disadvantaged because the current agreement continues to be beneficial to Canada, the more powerful state.

The Seasonal Agricultural Workers Program is vastly in favour of the Canadian agricultural businesses and abuses the approximately 13000 Mexican citizens who participate each year. These workers receive little help from their consulate, and even UN conventions cannot come to their aid, as Canada has refused to sign on to the relevant documents. Their unique status as "foreign workers" isolates and immobilizes them, ensuring they cannot enjoy a single right that Canadian citizens, landed immigrants and refugees take for granted here. It is not only the individual workers who suffer; the Mexican economy is also disadvantaged by this program. Canada, a country claiming to be democratic and just, is complicit in the underdevelopment of Mexico and its people. The question is whether or not civil society in Canada can help change these injustices. 


\section{Bibliography}

Clarkson, S. (2008). Does North America exist? Governing the continent after NAFTA and 9/11. Toronto: University of Toronto Press.

Drache, D. (2008). Big picture realities: Canada and Mexico at the crossroads. Waterloo, Ont.: Wilfrid Laurier University Press.

Lee, M. S. (Director). (2003). El Contrato [Documentary]. Canada: National Film Board.

Hennebry, J. (2008). Bienvenidos a Canadá? Globalization and the Migration Industry. Canadian Studies in Population, 35(2). Retrieved July 17, 2011, from http://www.canpopsoc.org/journal/CSPv35n2p339.pdf

Mapping Migration from the Americas - Home Page. (n.d.). Mapping Migration from the Americas. Retrieved July 16, 2011, from http://www.mappingmigration.com/homeenglish.html

Samaniego, N. (1998). Globalization, economic growth and the labour market in North America. Migration, free trade and regional integration in North America (pp. 51, 52). Paris: Organization for Economic Co-operation and Development.

Seasonal Agricultural Workers - Government of Canada - Foreign Worker Program. (n.d.). Human Resources and Skills Development Canada. Retrieved July 17, 2011, from http://www.hrsdc.gc.ca/eng/workplaceskills/foreign_workers/ei_tfw/saw_tfw.shtml

Verduczo, G., \& Unger, K. (1998). The impact of migration on economic development in Mexico. Migration, free trade and regional integration in North America (pp. 108-11). Paris: Organization for Economic Co-operation and Development. 
Second Year Paper

Citation Style: MLA 